\title{
Tamyiz; a Quantum Learning Method for Qawaid Instruction
}

\author{
Eka Rizal $^{1}$, Oktarina Yusra $^{2}$, Zikra Wahyuni $^{3}$, Hurriyatus Sa'adiyah ${ }^{4}$ \\ \{zikramaiza@gmail.com ${ }^{1}$,riena_nabilah@yahoo.com ${ }^{2}$, zikrawahyuni@gmail.com ${ }^{3}$, \\ ham909398@gmail.com ${ }^{4}$ \} \\ Faculty of Education and Teacher Training Institut Agama Islam Negeri (IAIN) Bukittinggi, \\ Indonesia ${ }^{1,2,3,4}$
}

\begin{abstract}
In general, Qawaid is one of important part in Arabic instruction. It related with other language branchs such as; imla', khat, literature, balaghah etc.Qawaid helps the students to have language proficiency such as listening, speaking, reading and writng. In some Islamic boarding school, Qawaid instruction runs slowly, spending time, uninteresting, scary and it was caused by uninteresting, less communicative and monotonous method. This research aims to promote Tamyiz method which is quantum learning as the solution for Qawaid instruction.
\end{abstract}

Key words: Tamyiz, Quantum Learning, Qawaid, Arabic language

\section{Introduction}

Based on researchers and linguists perspective that the Arabic language is one of great importance and high status among the languages of the world. Perhaps, the most important features that they are the longest living languages and the oldest era so that its speakers today in this era, which we like to call the era of globalization and other times, and after a thousand and seven hundred years, arabian understood the poems, idioms, as Arabian still understand the poems of Abu Tammam and Al Mutanabi and the proverbial and poets of modernists.[1]

Perhaps,its survival is due to the virtue of the Al-Qur'an that protects it, it is the only holu that kept its original language and most of languages die among the age, except Arabic language. It will still alive from death based on the swear that Al-Qur'an will be alive among all the time. It can pass the factors from other sides that against Arabic. Eventhough, there is a swear, people are required to spread the Arabic to the schools and universities as effort to maintain Arabic existence.

Arabic can not separate from the development of Indonesia moslim. It was known since Islam entered to this era. In the beginning, usage of Arabic was related to worship, prayer, and Al-qur'an recitation but nowadays Arabic became part of religion interaction, social and knowledge. Then, some of Indonesia vocabulary was adapted from Arabic. Arabic which is taught as foreign language in Indonesia has been going on for long time. Indonesia moslim desire to learn Arabic is motivated to understand Islam dogma which is sourced from Alqur'an and Hadist that use Arabic as well as religious book such as fiqh, tafsir, and aqidah

Arabic instruction is identical with Islamic boarding school and Islamic junior high school. Then, there are no one of Islamic boarding school and Islamic junior high school which 
not teach Arabic. In addition, some of public school also teachs Arabic. Arabic are taught in elementary school, secondary, and college. One of important aspect in Arabic which taught in Islamic boarding school and Islamic junior high school is qawa'id (grammatical).Qawaid is important thing in Arabic because it relates with other lang4age branch such as; imlak, khat, literature and balaghah. Qawaid was able to reinforce language skill: listening, speaking, reading and writing skill. Qawaid became Indonesia Islamic boarding school learning material.

Qawaid contains Arabic rules about how to read the last word in the sentences structure (nahw) and words derivation pattern (sharaf). The knowledge about qawaid is part of Arabic instruction. 'Abdul Alim Ibrahim states: punctuation in the form of harakat and sukun at the last letter on each word is important because it influences the meaning. In order to giving the correct harakat, qawaid, nahw dan sharf, should be mastered.[2]

Qawaid is not the aims of Arabic instruction. It helps the students to compose the correct sentences, oral and written. However, some of Islamic boarding school and Islamic junior high school focus on qawaid aspect so then, spending much of students' time during study in Islamic boarding school. It seems qawaid instruction was not developed, memorization is given. Then, syair and rules is given which is complicated to comprehend. The problem that found in qawaid instruction effect on students' belief about Arabic instruction, Arabic is complicated to learn. However every language has different difficulity level based on their characteristic.

Based on the problem found in qawaid instruction, the method which is suitable, effective, efficient, innovative and fun is needed. According to Samiudin the aspect which takes attention is methodology aspect. The success of language instruction was depended on method because the learning activity depends on methodology.[3]

\subsection{Introduction of the Tamyiz Method}

Tamyiz method is technique which facilitates qawaid learning with reformulate nahwu and sharaf rules that teach through song. In the beginning, this method was proposed by Zaunal Fatin or Abaza, was born in 1969 in Indramayu. In 2009, he arranged Tamyiz method which contains reformulation of nahwu and sharaf rules which different with previous nahwu and sharaf book. The material is displayed in table for classifying letter, isim and fiil. All of materials are sung following the lyric of popular songs accompanied by applause or using musical instrument so, the learning activity is fun.

The composition of Tamyiz method is inspired by Abaza observation toward qawaid instruction used nazham (verses) Alfiyah Ibnu Malik lyric in some Islamic boarding school. The students enjoy singing verses so they able to memorize a thousand of verse which contains Arabic rules easily. However, they are difficult to comprehend the rules because it writes in Arabic, so they are difficult to use the rules in daily life. With considering the situation, Abaza rearrange the nahwu and sharaf material in Indonesia so the students understand it easily. The materials are taught through song following the popular song lyric like singing, cause students loves to sing. At the end, he taught qawaid and named it Tamyiz method.[4]

Tamyiz method appeared due to MS Kaban' request after going back from visiting to magbaroh Imam Syafi'I in Egypt. He wanted Indonesian children could adopt Imam Syafi'I point of view in which he was able to teach Al-Qur'an, hadith and tafsir in scientific gathering based education since 10 years old. His hyphotesis that if there are children who are awesome in 10 years old so that they can memorize,comprehend and teach Al-Qur'an, hadith and kutub turats can describe that there will be influential person behind that educate them using "method" that is usefull.[5] Based on this request, Abaza arranged tamyiz method. 
The term "Tamyiz" refers to Abaza's teacher and Abaza's uncle name, Kiyai Anas Tamyiz. He has big merit in teaching Al-qur'an, Arabic, and Islam to Abza as well as Indramayu society. In order to remember Kiyai Anas Tamyiz merit, Abaza name the instruction metod that he formulates with Tamyiz method.

\subsection{Tamyiz Method Instructional Principle}

The development of tamyiz method as Qawaid learning methodoly adopted the quantum learning principle which proposed by Georgi Lozanov[6], that suggestion influences the learning outcome, negative or positive. Quantum learning is way to give positive suggestion to students during learning process which can apply through; 1) create exciting atmosphere 2) dynamic planning 3) empowering a solid learning foundation, 4) organize the learning environtment, and 5) empowering learning skill. According to Bobby Deporter and Mike Hernacki Quantum learning model has some positive effect toward students: 1) create positive attitude, 2) increase learning motivation, 3) increase long-life learning skill, 4) increases students' self-confident, 5) increases learning results.[7]

As the development of quantum learning method, tamyiz method used the following learning principles:[4]

- Method is more important than material (al-thariqah ahammu min al-madah)[8]. The material which taught using tamyiz method is similar with nahwu and sharaf book, the important thing is teaching must fun. If the students enjoy the learning process so, the students will master the learning material automatically.

- Tamyiz method is suitable for all of age. This method is designed as simple as possible in order to easy to use for all age, this method use slogan: "the children are able, so do adult". The beginning step in arranging tamyiz method is simplification of nahwu and sharaf material, the material which arranged focused on the function rather than technical term, the linguistic material is rarely use in learning material.

- Teach with neuro linguistik, this principle is conducted with fun and active learning principle, the teacher was not allowed to teach with awkward, scary, and monotonous atmosphere. The learning process is balanced between work and play, between internal and external stimulus, the learning must impress the students, fun and meaningful. There are some cases that should be considered in language teaching with neuro linguistic approach 1) Delta condition (brief sleeping, unconscious, unthinking) not on suitable time to have learning activity, 2) Alpha condition (super learning, comfortable, relax, calm, happy, stable heart rate) appropriate time to learn, 3) Beta condition (conscious and post-activity, and worried) is a condition in which it not required to study, 4) Gamma condition (high mental activity, matching, stress and mad) is an activity while learning with reptile brain[9]. Tamyiz method efforts students' learning condition on alpha position, therefore students will get comfortable, relax and enjoying learning activity.

- Balancing of left and right brain. The instruction did by turn up the voice through song. All of song is sung with loud voice as effort to optimize the potential of right and left brain, repetition techniques to activate the subconscious brain, repetition through song facilitate the storage of information without memorization, the tamyiz method optimize the $12 \%$ left brain potential to understand, $33 \%$ right brain potential to memorization, meanwhile 55 $\%$ subconscious brain potential for long term memorization, with all of them the learning outcome will optimal.

- Training of Trainer (TOT), the tamyiz method instruction did through training model, afterward the students was able become trainer and teach the material to the others. This 
method makes students able to deliver the material for theiself, but it can teach to the others. The delivering phase, nahwu and sharaf rule, are sung following the popular song lyric, the process of intensive comprehension did by individual. The method is suitable for small group between 5-10 students.

- Learn firsthand practice, nahwu and sharaf instruction by using tamyiz method was done 10 times, afterward the teacher explaines the rules function then practice it. The distance between material and practice was no more than 2 hours. The first practice was done on Al-qur'an, Al baqarah. Afterward, the practice was continued with Arabic book which do not have punctuation. Practice has big part in learning, $12 \%$ from learning time is used for material and $88 \%$ is used for practice.

\subsection{Qawaid Material in Tamyiz Method}

Tamyiz method is not solely method, but the combination of learning material with methodology. The arrangement of tamyiz was begin with composing of the tamyiz method user guidance book which contain the user manual, qawaid material and practice sheets. The Tamyiz method was not same with other qawaid book, some of rules have been simple according to the function and the other rules did not write in the book because it often used.

The following qawaid learning material used tamyiz method[4];

- Word classification. In Qawaid book, word is divided become 3; isim, fi'il and huruf, in tamyiz method word is divided become four which begin with the sequences of huruf, ma'rifah, isim and fiil. Huruf and ma'rifah is displayed in one page column so that the students master it quickly. The column is given 1 to 26 numbers. The huruf group is bi jarring (huruf jar), kaana rafa'u nashaba (kaana wa akhawatuha), inna nashaba rafa'u (inna wa akhawatuha), laa nashaba linnakirah, illa nashaba lilmustatsna, yaa nashaba lilmudhaf, yaa nida', an yanshiba (huruf nashab), laa tajzum, lam tajzum, al-istitsna', assyarth, al-'athaf, al-istifham, attaukid, al-istiqbal, annafai, ni'ma bi'sa. Meanwhile the ma'rifah category is zharaf, maushul, isyarah and dhamir. The isim material is: the characteristic of isim, mufrad, mutsanna and jamak. fi'il material relates to fiil madhi, mudhari' and amar. The utilization of word term in word classification denotes to the word function, as result the word term is different with other Qawaid book. .

- Tashrif, contain derivation of isim dan fi'il which displayed in column. The material is completed with mujaarad material to recognize the base word form which got the changing: prefixes, insertion and suffixes

- I'rab, contains the material about awamilul ismi and awamilul fi'li which discuss about the changing of the last harakat factor on isim and fi'il, the material is completed with dengan marfu'at, manshubat, majzumat and majrurat.

- Jumlah, discuss about Arabic sentences structure which consist of jumlah ismiyah (the sentence which begin with isim), jumlah fi'liyah (the sentence which begin with fi'il) and syibu jumlah (sentences resembling). Besides jar majrur, zharaf mazhruf, mudhaf mudhaf ilaih, tamyiz method writer add maushuf shifah, isyarah musyar ilaih and maushul shilah to syibhul jumlah division. The addition was not found at the other qawaid book.

2 Tamyiz Method Instruction Steps

Qawaid instruction by using tamyiz method is conducted by follow the following rules[4]:

- Introduction. In this phase, the teacher prepares students condition to accep learning material, deliver the learning goal and motivate the students. teacher with students shout the yell together with loud voice "Tamyiz: mudah, mantap, Alhamdulillah", "santri 
Tamyiz: sik asik asik, jempolan". This activity is did in every introduction process to motivate and make students concentrate.

- Muraja'ah is done in order to connect the new material with previous material. in this step the teacher and students do learning material repetition by singing together. In every meeting, all of material is repeated from the first meeting till the last material. for example the material on the third meeting is taqdim al-khabar, teacher and students repeated the previous material about ahkam al-mubtada' and anwa' al-khabar, all of material are sung together with loud voice.

- Presentation of new material. new material is presented by teacher with singing the popular song lyric for example the material of huruf jar (bi, ka, li, la,--- ila, 'ala --- min, fi, 'an, zharaf, hatta) is sung following the children song "selamat ulang tahun" (selamat ulang tahun kami ucapkan, selamat panjang umur kita kan doakan, selamat sejahtera sehat sentosa, selamat panjang umur dan bahagia). The teacher repeated the song material till the students is able to adjust the material pronunciation with song lyric, afterward the teacher and students pronounce the material 10 times, then the teacher explaine the function of rules followed with example. The presentation is ended with question section.

- Practice. In this phase, the teacher guides the students to practice the material on practice sheet which put at the last part of Tamyiz book. Practice uses the pieces Al-baqarah verse so the student recognizes the base form of word easily. The practice of huruf jar material is done by using al-Baqarah verses: 1-5, then reading the pieces of verses completely, then teacher asks for word classification, did the letter or not. If it no, all of the students answers "not letter, it should be the others". If it yes, the teacher asks the students to underline the word, then ask whether the letter is huruf jar, if it is part of huruf jar, teacher and students are sung the song of huruf jar and it will continue till the fifth verse. In 1-5 verse, there are 9 huruf jar, it means the teacher and students sing the huruf jar 9 times as a result the students will memorize huruf jar automatically.

- The example of huruf jar practise: teacher asked is الْكَنَابُ huruf? The students answered: "not letter, it should be the others" is. $\bar{\gamma}$ huruf? The students answered: yes, then underline it, is it huruf jar? The students answered no. is رَيْبَ huruf? The students answered "not letter, it should be the others", is في huruf? The students answered: yes, then underline it. The teacher asks, is it huruf jar? The students answered: yes, if it huruf jar, let's sing huruf jar. is ¿-... huruf? The students answered "not letter, it should be the others". is huruf? The students answered "not letter, it should be the others". is ...」 huruf? The students answered: yes, then underline it. Let's sing huruf jar. Is الْمُنَّقِينَ huruf? The students answered "not letter, it should be the others". Then, It will continue till the students is able to identify huruf jar in al-Qur'an. When the learning process discusses isim and fiil, the teacher ask the students to give box symbol on isim and triangle symbol for fi' $i 1$.

3 The advantages and Disadvantages of Tamyiz method

In learning, there is not perfect methodoly, applicable for all of situation and condition.

One thing that needs to realize is each of method has advantages and disadvantages. The advantages of tamyiz method in qawaid instruction are listed below:

- The students learn qawaid with fun and rilex. It seems like they do not learn, because learning is conducted with singing together, claping hand and fun atmosphere.

- The simplification of material, the material which taught through tamyiz method is necessary material, the complicated term does not contain as a result the beginner will learn qawaid easily.

- This method is applicable for all of ages, children till adult. 
However, disadvantages of tamyiz method in qawaid instruction are listed below:

- Tamyiz method demands teacher's singing skill, the teacher who not able to sing or not confident will difficult used this methodoly.

- The difficulty in choosing song lyric and mathing it with qawaid material. some of qawaid material is not suitable with song lyric sometimes, it can disturb students learning concentration.

- Tamyiz method was not suitable for students who have qawaid knowledge background, because sometimes Tamyiz method used unpopular term in qawaid learning in order to simplification of rules such as the term of zharaf is included to huruf jar whereas in qawaid book zharaf is not included into huruf jar even the function of zharaf is same with huruf jar.

\section{References}

[1] S. I. Arman, "Al-Lughah al-Arabiyah, Makanatuha, wa Manahij Tadrisiha fi Iran al-Yaum," Nadwah Dauliyah Haul. tajribah ta'lim al-Lughah al-Arabiyah fi Indones., vol. 01, no. 01, 2011.

[2] A. A. Ibrahim, Al-Muwajjih al-Fanni li Muallim al-Lughah al-Arabiyah, 14th ed. Cairo: Dar alMaarif, 1991.

[3] Samiudin, "Peran metode untuk mencapai tujuan pembelajaran," J. Stud. Islam, vol. 11, no. 02, pp. 113-130, 2016

[4] Abaza, Tamyiz Pintar Tarjamah Qur'an 30 Juz dan Kitab Kuning, 2nd ed. Jakarta: Tamyiz Publishing, 2011.

[5] Mukroji, "Metode Tamyiz (Sebuah Formulasi Teori Nahwu Shorof Quantum," J. Kependidikan, vol. II, no. 1, pp. 161-184, 2014.

[6] A. Gani and J. Nasution, "Pembelajaran Edutaiment: Tinjauan Filosofis Pendidikan Islam," Ihya al-Arabiyah, vol. 2, no. 1, pp. 65-83, 2017.

[7] Z. Arifin and Q. Teaching, "Quantum Learning and Teaching Menuju Arah Pembelajaran Bermakna," alfikra, vol. 10, no. 1, pp. 76-95, 2011.

[8] A. G. Harahap, "Konsep Pendidikan Islam Perspektif Mahmud Yunus," Rekognisi, vol. 1, no. 1, pp. 35-46, 2016.

[9] E. Hairani, "Kohesi metode tamyiz dalam pelajaran bahasa arab di pesantren takhassus bayt tamyiz indramayu," Misykat, vol. 03, no. 02, pp. 99-124, 2018. 